\title{
Frontal Sinus Schneiderian Papilloma
}

National Cancer Institute

\section{Source}

National Cancer Institute. Frontal Sinus Schneiderian Papilloma. NCI Thesaurus. Code C6837.

A papilloma that arises from the ciliated respiratory mucosa that lines the frontal sinus. It is classified as inverted papilloma and oncocytic papilloma. 